\title{
PERLINDUNGAN DAN UPAYA HUKUM BAGI PEKERJA KARENA PEMUTUSAN HUBUNGAN KERJA SEPIHAK
}

\author{
Ida Bagus Kade Putra Manuaba(1), Ida Ayu Sadnyini( ${ }^{(2)}$ \\ goesadek@gmail.com ${ }^{(1)}$, iasadnyini@undiknas.ac.id(2) \\ Undiknas University, Denpasar, Bali
}

\begin{abstract}
The Industrial Relationship Pancasila as orientation of philosophy for the labor law, have a purpose to balancing the right and obligation of labor, industrialist and government. Issues in this research are how represif and prefentif legal protection and legal efforts for employees cause unilateral termination as result of heavy mistake according to Act Number 13 Year 2003 concerning Labor. The purpose of this research is to know and examines the legal protection and the legal efforts for employees cause unilateral termination. The conclusion from this researchthat the substace of regulation on legal protection for unilateral termination as result of heavy mistake, is not formulated yet clearly and comprehensiveness with the result that legal uncertainty for laborer. And then for resolve the conflict there is 2 alternative dispute resolution, with litigation process pass through the court or non litigation process.
\end{abstract}

Keyword: Act Number 13 Year 2003 Concerning Labor, Article 158, Industrial Relationship, Termination.

\footnotetext{
ABSTRAK

Hubungan industrial pancasila sebagai pedoman filosofis Hukum Ketenagakerjaan di Indonesia memiliki tujuan untuk menyeimbangkan hak dan kewajiban masing-masing pihak, baik pekerja, pengusaha dan pemerintah. Permasalahan yang dibahas dalam tesis ini adalah bagaimana perlindungan hukum represif dan prefentif dan upaya yang dapat ditempuh oleh pekerja yang mengalami pemutusan hubungan kerja secara sepihak akibat kesalahan berat oleh pengusaha berdasarkan ketentuan UndangUndang No. 13 Tahun 2003 Tentang ketenagakerjaan. Tujuan dari penulisan tesis ini adalah untuk mengetahui dan mengkaji perlindungan hukum terhadap pekerja yang terkena pemutusan hubungan kerja sepihak dan mengetahui upaya hukum yang dapat ditempuh oleh pekerja yang mengalami pemutusan hubungan kerja sepihak. Dari hasil penelitian ini diperoleh kesimpulan bahwa substansi peraturan tentang perlindungan hukum terhadap pekerja yang mengalami pemutusan hubungan kerja secara sepihak yang tedapat dalam pasal 158 Undang-Undang No.13 Tahun 2003 belum dirumuskan secara jelas dan komprehensif sehingga menimbulkan ketidakpastian hukum. Selanjutnya dalam menyelesaikan perselisihan tersebut terdapat 2 alternatif penyelesaian sengketa baik itu melalui jalur litigasi yaitu melalui pengadilan atau dengan menggunakan jalur non litigasi.

Kata Kunci: Undang-Undang No.13 Tahun 2003 Tentang Ketenagakerjaan, Pasal 158, Hubungan Industrial, Pemutusan hubungan kerja.
} 


\section{PENDAHULUAN}

Hubungan Industrial di Indonesia didasarkan pada Hubungan Industrial Pancasila yakni hubungan antara para pelaku proses produksi barang dan jasa (Pekerja, Pengusaha dan Pemerintah) yang didasarkan atas nilai-nilai yang merupakan manifestasi dari keseluruhan sila-sila Pancasila dan Undang-Undang Dasar 1945 yang tumbuh dan berkembang di atas kepribadian bangsa dan kebudayaan nasionallndonesia. ${ }^{1}$ Peran serta pemerintah dalam mewujudkan Hubungan Industrial Pancasila ditunjukkan dengan disempurnakannya Undang-Undang yang mengatur mengenai ketenagakerjaan yaitu Undang-Undang No. 13 Tahun 2003 Tentang Ketenagakerjaan (Selanjutnya disebut UU No.13 Tahun 2003), yang bertujuan untuk memberdayakan dan mendayagunakan tenaga kerja secara optimal dan manusiawi, mewujudkan pemerataan kesempatan kerja dan penyediaan tenaga kerja yang sesuai dengan kebutuhan pembangunan nasional dan daerah, memberikan perlindungan dan kesejahteraan kepada tenaga kerja, serta meningkatkan kesejahteraan tenaga kerja dan keluarganya. Hadirnya Undang-Undang Ketenagakerjaan setidaknya secara hukum hak-hak normatif tenaga kerja telah dilindungi. Meskipun pada kenyataannya tidak bisa dipungkiri bahwa problem Hubungan Industrial sangatlah kompleks dan terkadang hadirnya Undang-Undang tersebut dirasa masih belum cukup menjadi pelindung bagi pekerja.

Pemutusan Hubungan Kerja (Selanjutnya disingkat PHK) sebagai salah satu permasalahan yang kompleks dalam hubungan industrial telah di atur dalam UU No.13 Tahun 2003, sehingga ada acuan yang dapat digunakan oleh pekerja untuk mencermati PHK yang dilakukan oleh pemberi kerja. Sementara itu, demi menyelesaikan sengketa yang kerap terjadi dalam PHK, pemerintah juga telah menetapkan Undang-Undang Republik Indonesia Nomor 2 Tahun 2004 tentang Penyelesaian Perselisihan Hubungan Industrial.Dalam hal PHK yang dilakukan oleh pihak pemberi kerja kepada pekerja secara sepihak akibat dari pekerja melakukan kesalahan berat, sebagaimana yang tercantum dalam pasal 158 UU Ketenagakerjaan, seperti melakukan perbuatan yang merugikan

${ }^{1}$ Hadi Setia Tunggal, 2016, Pengantar Hubungan Industrial, Harvarindo, Jakarta, h.330 
perusahaan, misalnya mencuri atau menggelapkan asset perusahaan, melakukan perbuatan yang mengganggu ketertiban umum di lingkungan pekerjaan, atau melakukan perbuatan lainnya yang bertentangan dengan Hukum yang berlaku di Indonesia dengan ancaman pidana penjara 5 tahun atau lebih, maka pihak pengusaha dapat langsung melakukan PHK terhadap pekerja bersangkutan. UU No.13 Tahun 2003 memberikan penjabaran pengertian "Kesalahan berat", sehingga dalam praktek kualifikasi "kesalahan berat" yang diatur dalam Pasal 158 ayat (1) menjadi terbatas. Dengan perkataan lain, tidak boleh ada kualifikasi perbuatan lain yang digolongkan menjadi kesalahan berat, dalam hal inilah terjadi norma kabur.

Selain itu alasan kesalahan berat pada pokoknya mengatur mengenai perbuatan pidana yang diatur dalam KUHP, sehingga untuk menyatakan pekerja telah melakukan kesalahan berat harus atas dasar pekerja tertangkap tangan, ada pengakuan pekerja bersangkutan atau bukti lain berupa laporan kejadian yang dibuat oleh pihak berwenang, di perusahaan yang bersangkutan, dengan didukung oleh dua orang saksi. Kata "atau" dalam pasal tersebut dapat menimbulkan persepsi yang berbeda-beda artinya apabila salah satu isi dari pasal tersebut terpenuhi maka pengusaha dapat langsung melakukan PHK terhadap pekerjanya, padahal bisa saja pekerja yang tertangkap tangan membawa asset perusahaan dilakukan dengan tidak sengaja, atau ada temannya yang berusaha menjebak pekerja tersebut. Tindakan tersebut bertentangan dengan asas Praduga Tak Bersalah (Presumption Of Innocence), karena belum mendapatkan putusan hukum yang tetap (inkracht).

Surat edaran Menteri Tenaga Kerja dan Transmigrasi RI Nomor SE-13/MEN/SJ-HK/I/2005 tentang Putusan Mahkamah konstitusi Nomor 012/PUU-I/2003 tentang Ketenagakerjaan terhadap UUD 1945 menjelaskan bahwa Mahkamah Konstitusi menyatakan bahwa UU Nomor 13 Tahun 2003 Tentang Ketenagakerjaan, khusus pasal di bawah ini tidak mempunyai kekuatan hukum mengikat. Menurut Putusan Mahkamah konstitusi Nomor 012/PUU-I/2003 menjelaskan bahwa keberadaan Pasal 158 UU Nomor 13 tahun 2003 tentang Ketenagakerjaan memberikan kemungkinan bagi perusahaan untuk langsung melakukan PHK terhadap pekerjanya ketika diduga melakukan tindak pidana berat, walaupun 
kasusnya belum terbukti dan mempunyai kekuatan hukum tetap. ${ }^{2}$

Berdasarkan hal tersebut menurut penulisterjadikekaburan norma,sebab UU No.13Tahun2003 sebagai regulasi Ketenagakerjaan terbaru justru tidak mengakomodasi hal ini. Sebab Undang-Undang tersebut tidak menyatakan bahwa PHK merupakan hal yang dilarang apabila pekerja baru diduga melakukan tindakan pidana yang belum terbukti dan memiliki kekuatan hukum tetap. Selanjutnya jika dilihat dari perspektif upaya hukum yang dapat dilakukan pekerja yang mengalami PHK secara sepihak, pemerintah telah membuat peraturan PerundangUndang yang mengatur tentang hal tersebut, yaitu Undang-Undang No.2 Tahun 2004 tentang Penyelesaian Perselisihan Hubungan Industrial.

\section{TINJAUAN PUSTAKA}

\section{Pengertian dan Konsep Teoritis Hubungan Industrial}

UU No. 13 Tahun 2003 menyebutkan pengertian Hubungan Industrial sebagai suatu sistem hubungan yang terbentuk antara para pelaku dalam proses produksi barang dan atau jasa yang terdiri dari unsur pengusaha, pekerja atau buruh, dan pemerintah yang didasarkan pada nilai-nilai Pancasila dan UUD $1945 .^{3}$

Hubungan Industrial Pancasila mengakui dan meyakini bahwa bekerja bukan hanya bertujuan untuk mencari nafkah saja, akan tetapi sebagai pengabdian manusia kepada tuhannya, kepada sesama manusia, dan kepada masyarakat, bangsa dan Negara. Hubungan Industrial Pancasila ini juga tidak menganggap manusia sebagai faktor produksi belaka, tetapi sebagai manusia pribadi dengan segala harkat dan martabatnya, Selain itu Hubungan Industrial Pancasila melihat antara pekerja dengan pengusaha bukanlah mempunyai kepentingan yang bertentangan, akan tetapi mempunyai kepentingan yang sama yaitu kemajuan perusahaan. Perusahaan yang maju dapat meningkatkan kesejahteraan semua pihak.

${ }^{2}$ http://m.hukumonline.com/berita/baca/lt4fde49d6569fc/penerapan-phkkarena-kesalahan-berat-pasca-putusan-mk-broleh-willy-farianto- Diakses tanggal 3 Mei 2017

3 Sumanto, 2014,Hubungan Industrial (Memahami dan Mengatasi Potensi Konflik Kepentingan Pengusaha-Pekerja Pada Era Modal Global), CAPS, Yogyakarta, h.2 


\section{Pengertian Perselisihan Hubungan Industrial}

Perselisihan Hubungan Industrial adalah perbedaan pendapat yangmengakibatkan pertentangan antara Pengusaha atau gabungan Pengusahadengan Pekerja/Buruh atau Serikat Pekerja/Serikat Buruh karena adanyaperselisihan mengenai hak, perselisihan kepentingan perselisihanpemutusan hubungan kerja danperselisihan antar serikat pekerja/serikat Buruh dalam satu perusahaan. ${ }^{4}$

\section{Pengertian Pemutusan Hubungan Kerja}

Pengertian PHK adalah pengakhiran hubungan kerja karena suatu hal tertentu yang mengakibatkan berakhirnya hak dan kewajiban antara pekerja dan pengusaha. Menurut Pasal 61 UU No.13 Tahun 2003 PHK dapat terjadi apabila : Pekerja meninggal dunia, adanya putusan pengadilan atau LPPHI yang telah memiliki kekuatan hukum tetap, adanya keadaan atau kejadian tertentu yang dicantumkan dalam perjanjian kerja, Peraturan perusahaan, atau PKB yang dapat menyebabkan berakhirnya hubungan kerja.

\section{METODE PENELITIAN}

\section{Desain Penelitian}

Penelitian dalam tesis ini adalah penelitian yuridis normatif, penelitian hukum dalam hal ini norma kabur (vague van normen) terkait dengan pengaturan perlindungan hukum terhadap pekerja yang di PHK berdasarkan UU No. 13 Tahun 2003,khususnya Pasal 158 tentang PHK karena kesalahan berat.

Selanjutnya untuk menjawab persoalan dalam penelitian ini, dianalisis dengan Teori perlindungan hukum dan teori sistem hukum untuk menganalisis rumusan masalah pertama, dan teori keadilan untuk menganalisis rumusan masalah kedua. Data yang diperoleh disajikan dengan langkah deskripsi, interpretasi, dan argumentasi selanjutnya penyimpulan bahan hukum dilakukan dengan cara deduktif yaitu dengan menarik suatu kesimpulan dari data-data yang sifatnya umum ke khusus.

${ }^{4}$ Pasal 1 angka 1 UU No. 2 Tahun 2004 tentang Penyelesaian Perselisihan Hubungan Industrial 


\section{Jenis dan Sumber Data}

Penelitian yang dilakukan kaitannya dalam penulisan tesis ini adalah jenis penelitian yuridis normatif, Penelitian hukum normatif adalah penelitian hukum yang dilakukan dengan cara meneliti bahan pustaka atau bahan sekunder belaka. ${ }^{5}$ Penelitian hukum dalam hal ini norma kabur (vague van normen) dengan permasalahan PHK secara sepihak, yang berdasarkan pada ketentuan Pasal 158 UU No. 13 Tahun 2003 Tentang Ketenagakerjaan.Sesuai dengan jenisnya, penelitian yuridis normatif merupakan penelitian hukum yang dilakukan dengan cara meneliti bahan pustaka atau data sekunder belaka. ${ }^{6}$ Data sekunder di bidang hukum, menurut Ronny Hanitijo Soemitro, ${ }^{7}$ dapat dibedakan menjadi:Bahan hukum primer, Bahan hukum sekunder, Bahan hukum tertier.

Penelitian mengenai pemutusan hubungan kerja secara sepihak ini dilakukan dengan menggunakan pendekatan sebagai berikut :Statute Approach (Pendekatan perundang-undangan), Conseptual approach (Pendekatan konsep hukum), Analitical Approach (Pendekatan Analitis).

\section{Teknik Pengumpulan Data}

Pengumpulan bahan hukum dilakukan melalui studi dokumentasi. Bahan hukum yang diperoleh, diinventarisasi dan diidentifikasi kemudian dilakukan pengklasifikasian bahan-bahan sejenis, mencatat dan mengolahnya secara sistematis sesuai dengan tujuan dan kebutuhan penelitian. Tujuan dari teknik dokumentasi ini adalah untuk mencari konsepsi-konsepsi, teori-teori, pendapat-pendapat, penemuan-penemuan yang berhubungan dengan permasalahan penelitian.

\section{Teknik Analisis Data}

Setelah langkah pengumpulan bahan hukum dengan sistem dokumentasi lengkap, maka dilanjutkan dengan proses analisis. Analisis dalam penelitian tesis ini menggunakan langkah-langkah sebagai berikut:

5Soerjono Soekanto dan Sri Pamudji, 2013, Penelitian Hukum Normatif Suatu Tinjauan Singkat, PT Raja Grapindo Persada, Jakarta,h.13

${ }_{6}$ Soerjono Soekanto dan Sri Pamudji, Loc.Cit.,

7Ronny Hanitijo Soemitro, 1994, Metodelogi Penelitian Hukum dan Jurumetri, Ghalia Indonesia, Jakarta,h.12 
Deskripsi (description), Interpretasi (interpretation), Argumentasi (argumentation). Selanjutnya dianalisis dengan menggunakan metode analisis kualitatif didasarkan atas pertimbangan data yang dianalisis diperoleh dari berbagai sumber. Selanjutnya untuk menjawab persoalan dalam penelitian ini, metode atau cara penyimpulan bahan hukum dilakukan dengan cara deduktif.

\section{PEMBAHASAN}

\section{Perlindungan Hukum Terhadap Pekerja Yang Terkena PHK Sepihak. Pengertian Dan Tujuan Perlindungan Hukum Terhadap Pekerja}

Pengertian perlindungan hukum adalah suatu perlindungan yang diberikan terhadap subyek hukum dalam bentuk perangkat hukum baik yang bersifat preventif maupun yang bersifat represif, baik yang tertulis maupun tidak tertulis.Menurut Philipus M. Hadjon berpendapat bahwa perlindungan hukum adalah perlindungan akan harkat dan martabat, serta pengakuan terhadap hak-hak asazi manusia yang dimiliki oleh subyek hukum berdasarkan ketentuan hukum dari kesewenangan. ${ }^{8}$ Selain itu, menurut Satjipto Raharjo perlindungan hukum adalah upaya untuk memberikan perlindungan kepada masyarakat agar dapat menikmati semua hak-hak yang diberikan oleh hukum. ${ }^{9}$ Dari pengertian mengenai perlindungan hukum tersebut dapat ditarik suatu kesimpulan bahwa yang dimaksud perlindungan hukum adalah suatu upaya yang dilakukan oleh Negara kepada subyek hukum untuk melindungi hak-hak subyek hukum baik secara preventif maupun represif. Mengenai pengertian perlindungan hukum terhadap pekerja dapat diartikan sebagai upaya yang dilakukan untuk memberikan perlindungan kepada pekerja untuk menikmati hakhaknya dan mencegah terjadinya pelanggaran yang dilakukan oleh majikan atau pengusaha yang diatur dalam peraturan perundang-undangan. Adapun tujuan diberikannya perlindungan hukum terhadap tenaga kerja adalah untuk menjamin berlangsungnya sistem hubungan kerja secara harmonis tanpa disertai adanya tekanan dari pihak yang kuat kepada pihak yang lemah.

${ }^{8}$ Philipus M. Hadjon, 1987, Perlindungan Bagi Rakyat di Indonesia, PT. Bina Ilmu, Surabaya, h. 1-2

9Satjipto Raharjo, 2000, IImu Hukum, Cetakan V, PT.Citra Aditya Bakti, Bandung, h.53 


\section{Sarana dan Obyek Perlindungan Hukum Terhadap Pekerja yang di PHK Akibat kesalahan berat}

Terdapat dua sarana perlindungan hukum, hal ini sebagaimana yang dijelaskan oleh Philipus M. Hadjon bahwa perlindungan hukum dibagi menjadi 2 (dua), yaitu:

1. Perlindungan hukum preventif yaitu perlindungan hukum yang bertujuan untuk mencegah terjadinya suatu sengketa.

2. Perlidungan hukum represif adalah perlindungan hukum yang bertujuan untuk menyelesaikan suatu sengketa. ${ }^{10}$

Perlindungan hukum preventif ditandai dengan dibentuknya peraturan perundang-undangan yang dimaksudkan untuk membatasi tindakan-tindakan seseorang yang dapat melanggar hak daripada orang lain. Terkait dengan norma kabur yang terdapat dalam UU No. 13 Tahun 2003 Pasal 158 ayat 2, yang memperbolehkan pengusaha melakukan PHK secara sepihak tanpa mendapatkan ijin dari LPPHI, maka perlindungan prefentif yang dapat dilakukan adalah sebaiknya pekerja tersebut di scorsing terlebih dahulu hingga PHK tersebut mendapatkan putusan hukum yang tetap atau mendapatkan ijin dari LPPHI. Hal terdapat dalam Pasal 155 ayat (3) Undang-undang No.13 Tahun 2003 Tentang Ketenagakerjaan yang isinya untuk memberhentikan pekerja sementara waktu dan pengusaha tetap melaksanakan kewajibannya membayar upah dan hak-hak pekerja.

Perlindungan hukum represif ditandai dengan menerapkan sanksi terhadap pelaku yang diberikan apabila terjadi pelanggaran terhadap aturan yang telah ditetapkan. Untuk memberikan perlindungan hukum terhadap pekerja maka Pemerintah membentuk UU No. 13 Tahun 2003 dan UU No. 2 Tahun 2004 yang merupakan substansi dari suatu hukum Ketenagakerjaan.

Berdasarkan ketentuan pasal 158 ayat (1) UU No.13 Tahun 2003 pengusaha dapat memutuskan hubungan kerja terhadap pekerja/buruh dengan alasan pekerja/buruh telah melakukan kesalahan berat sebagai berikut:

1. melakukan penipuan, pencurian atau penggelapan barang dan/atau uang milik perusahaan;

${ }^{10}$ Philipus M. Hadjon, Op. Cit., h. 5 
2. memberikan keterangan palsu atau yang dipalsukan sehingga merugikan perusahaan;

3. mabuk,meminum minuman keras yang memabukkan, memakai dan/atau mengedarkan narkotika, psikotropika dan zat aditiktif lainnya di lingkungan kerja;

4. melakukan perbuatan asusila atau perbuatan perjudian di lingkungan kerja;

5. menyerang, menganiaya, mengancam, atau mengintimidasi teman sekerja atau pengusaha di lingkungan kerja;

6. membujuk teman sekerja atau pengusaha untuk melakukan perbuatan yang bertentangan dengan peraturan perundang-undangan;

7. dengan ceroboh atau sengaja merusak atau membiarkan dalam keadaan bahaya barang milik milik perusahaan yang menimbulkan kerugian bagi perusahaan;

8. dengan ceroboh atau sengaja membiarkan teman sekerja atau pengusaha dalam keadaan bahaya di tempat kerja;

9. membongkar atau membocorkan rahasia perusahaan yang seharusnya dirahasiakan kecuali untuk kepentingan negara atau

10. melakukan perbuatan lainnya di lingkungan perusahaan yang diancam pidana penjara 5 (lima) tahun atau lebih. ${ }^{11}$

Kriteria kesalahan berat yang diatur dalam pasal 158 ayat (1) UU No. 13 Tahun 2003 itu pada dasarnya dapat disejajarkan dengan delict (perbuatan melanggar hukum) kejahatan, yang diatur dalam Buku kedua Wetboek van starfrecht.Diputuskannya pekerja telah melakukan kesalahan berat, haruslah didasarkan pada prosedur yang diatur dalam pasal 158 ayat (2) UU No. 13 Tahun 2003, yaitu :

1. pekerja / buruh tertangkap tangan;

2. ada pengakuan dari pekerja/ buruh yang bersangkutan, atau ;

3. bukti lain berupa laporan kejadian yang dibuat oleh pihak yang berwenang di perusahaan yang bersangkutan dan didukung oleh sekurang-kurangnya 2 (dua) orang saksi. ${ }^{12}$ 158 Ayat 1

11 Undang-Undang No. 13 Tahun 2003 Tentang Ketenagakerjaan Pasal 158 Ayat 2

12 Undang-Undang No. 13 Tahun 2003 Tentang Ketenagakerjaan Pasal 
Tiga syarat yang ditetapkan dalam pasal 158 ayat (2) UU No. 13 Tahun 2003 harus bersifat kumulatif, tidak boleh alternatif. Maksudnya adalah kesemua syarat yang ditetapkan dalam pasal 158 ayat (2) UU No. 13 Tahun 2003 itu harus ada, tidak adanya salah satu syarat dari ketiga syarat itu menjadikan putusan pengusaha / majikan bahwa pekerja telah melakukan kesalahan berat tidak dapat diterima. Namun seringkali UU No.13 Tahun 2003 itu ditafsirkan sebagai syarat alternatif dan bukan sebagai syarat kumulatif. Dikatakan secara penafsiran bahwa itu menunjukkan sebagai syarat alteranatif karena antara pasal 158 ayat (2) b dan pasal 158 ayat (2) c UU No. 13 Tahun 2003 menyebutkan kata "atau" bukan "dan". Penggunaan kata dan dengan kata atau dalam konteks bahasa hukum membawa akibat yang berlainan. Seharusnya redaksional pasal 158 ayat (2) UU No. 13 Tahun 2003 itu tertulis dan kekhawatiran akan terjadinya penyalahgunaan yang akan terjadi di masyarakat dapat dipahami. Mengingat apabila syarat yang terdapat dalam pasal 158 ayat (2) UU No. 13 Tahun 2003 dapat hanya dipakai salah satu saja. Misalnya seorang pekerja yang bekerja di sebuah perusahaan, pada saat akan pulang dan menjalani check body (pemeriksaan oleh petugas keamanan di pintu keluar tempat kerja) kedapatan telah membawa barang milik perusahaan tanpa alasan yang dapat dibenarkan. Atas dasar telah terpenuhinya syarat pertama yaitu pekerja telah tertangkap tangan dengan tanpa diikuti syarat kedua dan ketiga maka pekerja tersebut saat itu juga dapat di PHK secara sepihak. Misalnya kenyataannya pekerja tersbut tidak pernah mengambil barang milik perusahaan. Atau karena ada orang lain yang sengaja ingin mencelakakan pekerja tersebut supaya ia dapat di PHK. Tidak ada gunanya apabila si pekerja bersikeras menolak tuduhan itu. Begitu juga apabila pekerja tersebut tidak pernah mau mengakui bahwa ia telah mencuri apalagi mau membuat surat pengakuan bahwa ia telah mencuri.

Kekurang cermatan dalam merumuskan norma hukum tanpa memahami konsep bahasa hukum memang dapat berpengaruh pada keberlakuan hukum. Apabila dilakukan analisis maka ketentuan pasal 158 ayat (2) UU No. 13 Tahun 2003 itu tidak memenuhi syarat keberlakuan yuridis dari suatu peraturan perundang-undangan. Ketentuan hukum terhadap PHK secara sepihak karena kesalahan berat memerlukan kajian 
yang lebih jelas dan komprehensif, karena belum mencerminkan suatu pasal yang sempurna dan belum memenuhi syarat hukum yang baik, di samping hukum harus menciptakan suatu keadilan (fairness), hukum juga harus memenuhi unsur Predictability yang mensyaratkan bahwa hukum tersebut mendatangkan kepastian hukum (Legal certainty). ${ }^{13}$

\section{Upaya Penyelesaian Perselisihan Hubungan Industrial. Penyelesaian Melalui Mekanisme Bipartit}

Penyelesaian melalui perundingan bipartit, adalah perundingan antara pekerja/buruh atau Serikat Pekerja/Serikat Buruh dengan pengusaha untuk menyelesaikan perselisihan hubungan industrial. "Selama ini penyelesaian bipartit dikenal dengan cara negosiasi yaitu komunikasi dua arah yang dirancang untuk mencapai kesepakatan pada saat kedua belah pihak memiliki kepentingan yang sama maupun berbeda". 14

\section{Penyelesaian Melalui Mediasi}

"Mediasi Hubungan Industrial yang selanjutnya disebut Mediasi adalah penyelesaian perselisihan hak, perselisihan kepentingan, perselisihan pemutusan hubungan kerja, dan perselisihan antara Serikat Pekerja/Serikat Buruh hanya dalam satu perusahaan melalui musyawarah yang ditengahi oleh seorang atau lebih mediator yang netral". ${ }^{15}$ Penyelesaian perselisihan melalui Mediasi, mengutamakan penyelesaian musyawarah untuk mufakat, dan apabila dalam perundingan tersebut dicapai kesepakatan, dibuat Perjanjian Bersama yang ditanda tangani oleh para pihak dan disaksikan oleh Mediator dan didaftarkan di Pengadilan Hubungan Industrial untuk mendapatkan Akta bukti pendaftaran.

\footnotetext{
${ }^{13}$ Max Weber, 1994, Law In Economy And Society, Harrow and Heston Publishers, New York, p. 46

${ }^{14}$ Suyud Margono, 2000,ADR dan Arbitrase :_ProsesPelembagaan dan Aspek Hukum, Ghalia Indonesia, Jakarta, h.49

${ }^{15}$ http://www.hukumtenagakeria.com/perundingan-bipartit-antarapengusaha-dan-pekerja/\#more-131 diakses tanggal 02 Desember 2017
} 


\section{Penyelesaian Melalui Konsiliasi}

Penyelesaian perselisihan hubungan industrial yang selanjutnya disebut konsiliasi adalah,penyelesaian perselisihan kepentingan, perselisihan pemutusan hubungan kerja, dan perselisihan antara Serikat Pekerja/Serikat Buruh hanya dalam satu perusahaan melalui musyawarah yang ditengahi oleh seorang atau lebih konsiliator yang netral.Konsiliator dalam menyelesaikan perselisihan hubungan industrial pada dasarnya adalah melalui musyawarah untuk mufakat. Dalam perundingan yang mencapai kesepakatan, dibuat Perjanjian Bersama yang ditandatangani oleh para pihak dan disaksikan oleh Konsiliator, untuk didaftarkan pada Pengadilan Hubungan Industrial guna mendapatkan akta bukti pendaftaran. ${ }^{16}$

\section{Penyelesaian Melalui Arbitrase}

Arbitrase adalahpenyelesaian suatu perselisihan kepentingan dan perselisihan antar Serikat Pekerja/Serikat Buruh hanya dalam satu perusahaan, di luar Pengadilan Hubungan Industrial melalui kesepakatan tertulis yang putusannya mengikat para pihak dan bersifat final. Arbiter yang dimaksud disini adalah seorang atau lebih yang dipilih oleh para pihak yang berselisih dari daftar arbiter yang ditetapkan oleh Menteri untuk memberikan keputusan mengenai perselisihan kepentingan, dan perselisihan antar Serikat Pekerja/Serikat Buruh hanya dalam satu perusahaan yang diserahkan penyelesaiannya melalui Arbitrase yang putusannya mengikat para pihak dan bersifat final. ${ }^{17}$

\section{Penyelesaian Perselisihan Hubungan Industrial Melalui Pengadilan Hubungan Industrial Dan Mahkamah Agung}

Pengadilan hubungan industrial adalah Pengadilan Khusus yang dibentuk dilingkungan Pengadilan Negeri yang berwenang memeriksa, mengadili dan memberikan putusan terhadap perselisihan hubungan industrial. Pengadilan Hubungan Industrial merupakan upaya penyelesaian perselisihan dengan jalur litigasi.

${ }^{16}$ Undang-undang No.2 Tahun 2004 tentang Penyelesaian Perselisihan Hubungan Industrial.

17 Sudiarto, 2015,Negosiasi, Mediasi, dan Arbitrase, "Penyelesaian Sengketa Alternatif Di Indonesia”, Pustaka Reka Cipta, Bandung, h.62 


\section{PENUTUP}

\section{Simpulan}

Berdasarkan permasalahan yang dikemukakan diatas, maka dapat saya berikan kesimpulan sebagai berikut :

1. Perlindungan hukum terhadap pekerja yaitu,

a. Perlindungan hukum Preventif : adalah perlindungan hukum yang bertujuan untuk mencegah terjadinya suatu sengketa, dalam hal ketenagakerjaan pembentukan UU Ketenagakerjaan merupakan salah satu contoh tindakan kongkrit yang diberikan pemerintah sebagai sarana perlindungan preventif, selain itu Perjanjian Kerja Bersama (PKB) juga merupakan sarana perlindungan preventif, oleh karena itu PKB harus dirumuskan bersama (oleh kedua belah pihak) dengan baik. Terkait dengan norma kabur yg terdapat dalam pasal 158 ayat (2), maka upaya hukum preventif yang dapat dilakukan adalah sebelum pekerja di PHK, dan perkara yang terjadi belum mendapatkan putusan hukum tetap atau ijin dari LPPHI sebaiknya dilakukan scorsing terlebih dahulu, hal tersebut dapat melindungi hak-hak dari pekerja hingga ada putusan hukum tetap.

b. Perlindungan hukum represif : adalah perlindungan hukum yang bertujuan untuk menyelesaikan sengketa. Perlindungan hukum represif ini dilakukan dengan menerapkan sanksi yang diberikan terhadap pelaku yang melakukan pelanggaran. Hal ini dilakukan dengan harapan tidak akan terjadi lagi pelanggaran yang sama.

2. Upaya penyelesaian yang dapat ditempuh oleh tenaga kerja yang mengalami pemutusan hubungan kerja secara sepihak dapat diselesaikan dalam 2 (dua) jalur, yaitu penyelesaian perselisihan hubungan industrial di luar pengadilan dan melalui pengadilan hubungan industrial. Pertama diwajibkan melalui bipartit yang prosesnya melalui 3 (tiga) tahap yaitu, persiapan, perundingan dan setelah perundingan, bila perundingan gagal dilanjutkan dengan tripartite yang metode penyelesaiaannya melalui mediasi untuk mencapai kesepakatan Pasal 13 ayat (2) Undang-Undang No.2 Tahun 2004, apabila tidak menemukan titik temu dilanjutkan konsiliasi untuk mencapai kesepakatan Pasal 23 ayat (1) apabila tidak menemukan kesepakatan dilanjutkan melalui pengadilan hubungan industrial, 
terdapat dalam Pasal 55. Penyelesaian perselisihan melalui jalur pengadilan ditempuh 2 (dua) cara yaitu penyelesaian oleh Hakim Pasal 81 dan oleh Hakim Kasasi Pasal 113 Undang-Undang No. 2 tahun 2004 Tentang Penyelesaian Perselisihan Hubungan Industrial.

\section{Saran}

1. Hendaknya Undang-undang No.13 tahun 2003 tentang Ketenagakerjaan lebih rinci lagi dalam mengatur hak dan kewajiban pengusaha dan pekerja, sehingga memperkecil terjadinya perselisihan hubungan industrial, selain itu pemerintah khususnya instansi terkait lebih memperketat pengawasan dan menerapkan sanksi yang tegas sesuai dengan Undang-undang yang berlaku sehingga tidak semakin banyak pekerja yang menjadi korban akibat pemutusan hubungan kerja secara sepihak oleh pengusaha. Selain itu perusahaan diharapkan dapat beritikad baik dan mentaati perjanjian kerja yang dibuat oleh para pihak dan menjalankan kegiatan perusahaan dengan cara memprioritaskan pekerja agar jangan sampai terjadi pemutusan hubungan kerja secara sepihak.

2. Setiap perselisihan hubungan industrial yang terjadi diharapkan dapat diselesaikan dengan jalur non-litigasi, baik itu dengan perundingan bipartit, mediasi, konsiliasi maupun arbitrase, karena penyelesaian perselisihan dengan jalur non litigasi memiliki keunggulan seperti : penyelesaian perselisihan dapat diselesaikan dengan waktu yang lebih singkat, kemudian dari segi biaya juga lebih murah, selain itu penyelesaian perselisihan dengan non litigasi menganut prinsip win-win solution, jadi hubungan baik para pihak dapat terjaga. Kemudian kerahasiaan dari perselisihan yang terjadi dapat dijaga, sehingga tidak merusak nama baik perusahaan. 


\section{DAFTAR PUSTAKA}

\section{Buku:}

Hadjon, Philipus M., 1987, Perlindungan Bagi Rakyat di Indonesia, PT. Bina Ilmu, Surabaya.

Margono, Suyud, 2000,ADR dan Arbitrase : Proses Pelembagaan dan Aspek Hukum, Ghalia Indonesia, Jakarta.

Raharjo, Satjipto, 2000,IImu Hukum, Cetakan V, PT.Citra Aditya Bakti, Bandung.

Soekanto, Soerjono dan Sri Pamudji, 2013, Penelitian Hukum Normatif Suatu Tinjauan Singkat, PT Raja Grapindo Persada, Jakarta

Soemitro, Ronny Hanitijo, 1994, Metodelogi Penelitian Hukum dan Jurumetri, Ghalia Indonesia, Jakarta.

Sudiarto,2015, Negosiasi, Mediasi, dan Arbitrase, "Penyelesaian Sengketa Alternatif Di Indonesia", Pustaka Reka Cipta, Bandung.

Sumanto, 2014,Hubungan Industrial (Memahami dan Mengatasi Potensi Konflik Kepentingan Pengusaha-Pekerja Pada Era Modal Global), CAPS, Yogyakarta.

Tunggal, Hadi Setia, 2016,Pengantar Hubungan Industrial, Harvarindo, Jakarta.

Weber, Max, 1994,Law In Economy And Society, Harrow and Heston Publishers, New York.

\section{Peraturan Perundang-Undangan:}

Undang-Undang No. 2 Tahun 2004 tentang Penyelesaian Perselisihan Hubungan Industrial

Undang-Undang No. 13 Tahun 2003 Tentang Ketenagakerjaan

\section{Artikel Internet:}

http://m.hukumonline.com/berita/baca/lt4fde49d6569fc/penerapan-phk-

karena-kesalahan-berat-pasca-putusan-mk-broleh-willy-farianto-

Diakses tanggal 3 Mei 2017

http://www.hukumtenagakerja.com/perundingan-bipartit-antara-pengusahadan-pekerja/\#more-131 diakses tanggal 02 Desember 2017 